\title{
Important Points on Rewriting Old Stories for Children
}

\author{
Maryam Jalali \\ Department of Persian Language and Literature, Shahid Beheshti University, Tehran, Iran \\ E-mail: jalali_1388@yahoo.com
}

Doi:10.7575/aiac.alls.v.6n.6p.165

URL: http://dx.doi.org/10.7575/aiac.alls.v.6n.6p.165
Received: 26/07/2015

Accepted: 28/09/2015

\begin{abstract}
Various works with different genres can be applied to rewrite classic literature. Versified stories, unreal fictions and real stories are identified as texts which can be rewritten in a new texture. The first rewritten texts have been published long ago. The authors and researchers have been more knowledgeable in this regard particularly in the last two decades in order to carry out a remarkable development in this field. It should be considered that there are talented authors who realize the capability of these texts while analyzing them. As a matter of fact, this capability is referred to being recreated and turning into a new texture and structure. It seems as if these myths are supposed to step into a new universe where it is founded on written speech. This recreation is emerged because the society needs to take a look at its past in a modern version because modern children are going to read them.
\end{abstract}

Keywords: Rewriting, Old Story, children's literature, contemporary

\section{Introduction}

The addressee identifies the literature because if a work doesn't have any addressee, it sounds as though it has never been existed. Various addressees and needs have made literature be consistent and creative. Meantime, it is essential to pay attention to the needs and tendencies of children and adolescents. Since they have their specific characteristics of their age and have a different competency to fathom and read literature, they need to be particularly noticed. A successful rewriter is the one who knows the needs and specifications of his time and addressee then he can make the best out of this. The old stories and myths of ancient Iran are so precious that must be recreated by very expert ones to shimmer their glory and magnificence. The content and the theme can be retained but in a new structure. These points cannot guide the author; they should be dealt with the text literacy, though. And the author would better ask himself the following questions from the viewpoints of an adolescent:

- What are his possible themes?

- What structure and plot amuse him?

- What are his prominent figures? And how they should be introduced?

- How the symbols and descriptions of the texts should be?

- How should the language and syntactic structure of the text be?

- How can the scene design make him interested in the text?

In case the author scrutinizes the above points, he can motivate children and adolescents to follow their native art and literature. In contrast, if he neglects the point above while rewriting the stories, he can change children and adolescents into ones who have no ambition to read the precious classic texts of their native land. We are hopeful that the rewriters take this regard seriously to create Valuable quotations for the young adult generation.

The following five factors are introduced to evaluate children and adolescents books.

1 -The content and texture quality;

2-The quality of the structure;

3-Language and type of writing;

4-The quality of the illustrations;

5- The quality of representation.

As these factors are very general, they seem ambiguous. For example; the quality of texture and structure are too related to be separated from one another. The quality of texture and structure holds items such as plot, point of view, personification, description, interaction and, etc.

Language is the most dominant factor in comparison to content, texture and structure. A formalist theorist believes that non-familiarization is remarked as one of the most necessary story techniques. (Mohammadi,1996: 62) Recreation or non-non-familiarization is the most important element making a work prominent. This recreation is mostly observed in the content, texture and structure, but it is more tangible in texture and structure. 
In this regard, Babak Ahmadi says:" non-familiarization is happened through point of view, language applicability and plot assessment. The author is able to single out particular moments of the story, mix them together in the plot and create such astonishment' (Same, p. 63). According to Piaget, non-familiarization is referred to human's getting used to objects, phenomena and animal and human interactions (Same, p.15). Recreation is actually recognized as a human reaction in various situations and it is introduced as non-familiarization that it is the furthest place crossing the addressee's mind and it is against the mind's defined reaction; It might be the author's art to be able to create a new world. Curiosity and the anxiety to explore new horizons are considered as the most significant factors absorbing an adolescent to the stories exposing him to new experiences. It is recommended to separately scrutinize the intended factors.

\section{First Factor: Content and Theme}

The rewriter usually borrows the content and theme from the original author and he doesn't make any changes in it. So, it is not possible to interpret it. However, the important issue is how the rewriter specifies and chooses the type of story and processes it for his intended age group?

Mantvani states in his book- new trends in child literature- that "'although the children literature is not purely focused on pedagogical approaches, it is a pedagogical phenomenon in its place because it is a way reaches child from me to us'. (Jafarzadeh, 1984,p. 26) Reza Rahgozar says"' children should first learn about their childhood life and then they should try to comprehend issues not related to their childhood but vital for their future life like getting aquatinted with other nations and religions (Rahgozar,1987,p. 31-32).

Alipur quotes from Farrokh Sadeghi, a pioneer in children literature, two pints about texts suitable for children:

1-Texts should be coped with the age and easy to read.

2-The stories shouldn't directly induce training but try to enhance the social, historical and literal awareness. (Alipur, 1979, p. 15)

In fact, many people believe the pedagogical responsibility as an inevitable part of the child literature. Plato declares in this regard that:

Mothers and caregivers should be obliged to retell stories that we have accepted them. We should consider that stories nurturing children's soul is much more influential than their physical training. (Plato, 2000, p. 130)

\section{Second Factor: Language and Syntax/ Punctuations}

Roland Barthes writes in his book-criticism and the fact of language importance- that:

A writer is the one who is concerned to language and seeks through the depth of the language not the instrumentalism or the beauty. (Barthes, 1998, p.9)

It is clearly understood that language and way of writing is counted as the most important factor distinguishing child and adolescent literature from the adult one. However, there are some differences in choosing the proper words and syntax for the child and adolescent texts. In fact, simpler words should be used for younger ages.

What is the characteristic of a simple language?

According to Rahmandust, a simple language is the one which is easy to understand and the reader doesn't deal with the meaning of words but get involved with the sense and the spirit of the text. (Rahmandust, 1990, p. 22)

Today, different computer games, expansion of children social interactions and awareness, the domain of language application in various age groups are changing the boundary of the children's official language, so it is perfect to record such changes in order to contribute child literature. For example; this recognition can help the author write in a pattern which is comprehensible for illiterate children or the poorly educated ones and avoid difficult words and complicated expressions. In case his readers at very young ages, much simpler words must be chosen. Being familiar with the words expansion of children's official language is regarded as one of the most important knowledge. It is necessary for children researchers get to know with this knowledge:

The most important criteria for choosing words are based on the situation, topic, consistency and the cultural recognition of children and adolescents"' (Jalal, 2014,p.32)

One of the factors of not reading the text properly is related to the absence or mistakes in punctuations. Persian literature is very flexible in that any pausing can change the meaning or make it ambiguous. Therefore, this point must be precisely considered for children and adolescents age groups.

\section{Third Factor: Texture and Structure}

This is a general criterion and its subdivisions creating a story should be analyzed. They include: plot, personification, description or text symbols, interaction and so on. However, they are placed in the plot. 


\section{Plot}

From terminological point of view, plot is referred to the setting in which the author arranges the events to reach to his desirable ending. A plot consists of consecutive events which goes to climax and expected ending in the challenge of forces in contrast. (Irani, 1985, p. 164)

David Chambers illustrates the plot structure as below:

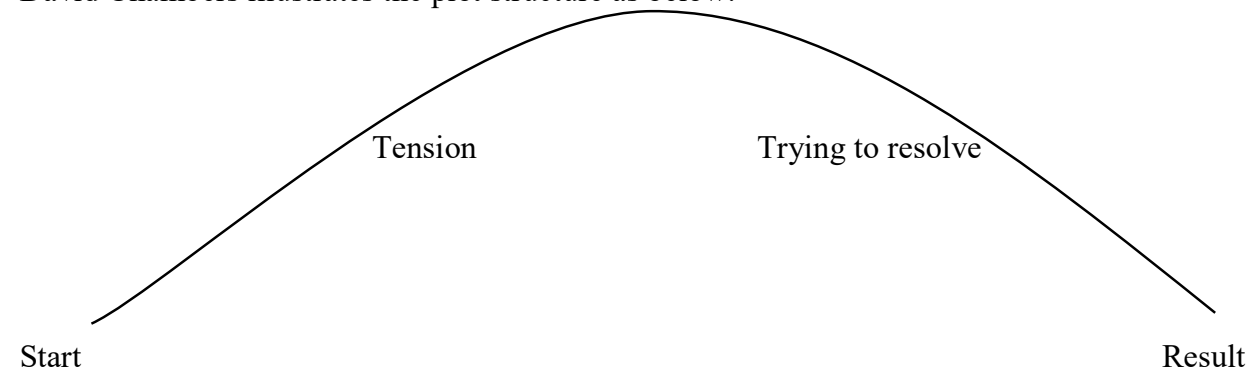

The most important part of the story is the beginning of it because it is the point absorbing the addressee. His is more prominent among children and adolescents because uninteresting subjects make them feel bored. Elizabeth Bytes on the importance of the beginning part of the story believes that: 'it is necessary to start a story dull at the first. The reader should be attracted to the story at the first lines or at the first two or three paragraphs or the first half of the page of the story. Describing the setting, type of story or the potential struggle might be required; however, they should be appropriately presented. The reader wants to know where his position is, he wants to accompany with the story characters and live with them.'’(Hejazi,2001,p.109).

The second important point is to logically introduce the events and make the believable. It means that the story events should look real. As the matter of fact, writer is the one who changes the strangest events into real one for the addressee. Isaac Siger thinks that children pay more attention to this issue than adults. (Same, p. 111)

The question is that how it is possible to make the plot believable and attractive? The interactions are considered as the most influential instrument in this regard.

\section{Interaction}

Mohammadi suggests some categories in his psychology book:

1-Main/auxiliary;

2-Verbal/nonverbal;

3- Real/imaginary;

4-Conceret/ abstract;

5- Asleep/awake;

6- Individual/in group.

He believes that adolescents are more eager to mind interactions because they constantly assess the situations. (Mohammadi, 1996, p.150)

What are the story core and interactions?

Prop thinks that after the beginning part of any fiction, a chain of functional interactions run the fiction. (Prop1989, p.78)

The specifications of these interactions include:

1-other interactions are formed on the axis of these ones or are considered as an action of them.

2- Functional interactions are the fundamentals from one situation to another.

The rewriter remarks the total point of the original author. The rewriter might not change the sequence of actions, but some parts of the plot might be more prominent for the sake of today's needs. For example; romantic interactions should be considered more in texts written for adolescents. The original author might have been more interested in describing the sceneries, jungles and palaces because of that time requirements, in contrast to the present addressee who are enthusiastic in palace description more. So, this gap should be filled the rewriter's art of writing.

\section{Text symbols/Description}

Description or the symbol is regarded as one of the factors making the plot more absorbing and magnificent: Mohammadi believes that if the interaction controls the movements of the structure, the symbols fundamentally express these movements and informing the reader about the situation of the story interactions and making the story language more tender are identified as the important functions of symbol. (Same,p. 156) 
Symbols can contribute the author to indirectly convey the information and the messages and also make the reader imagine deeper. This is more significant for young adults because young adults are not interested in taking and listening to advices, they want to experience and comprehend everything by themselves.

Furthermore, a great part of the story scenes depends on symbolizing. Hal believes that scene is made the best through imagination (Fard, 1998). This is true. Since we can't imagine a scene, we can't put the symbols into practice and illustrate it for the addressee. It is necessary to point out that conversation can help create the scene which shall be discussed in personification section.

Mohammadi scrutinizes the symbols from three aspects:

1- setting: place, time of interaction

2- Characters

3- language (real or virtual, assimilation, metaphoric) the story language can be defined both in simple or compound patterns (Mohammadi1996, p.159-160).

A critic should consider and assess two points: matching symbolizing in plot and theme; correctly applying symbols due to his addressee's needs and capabilities.

\section{Personification}

The methodology of the children literature criticism represents the children character in two main ways:

1- Applying the real personality without any changes in the physical appearance and/or his behaviors

2- Practicing some of the human attributes and treatments in shape of plant, animal characters, natural phenomena and creatures made by human mind (Same. p.174)

These characters can be applied for adolescents, but what makes the characters more attractive is how they are presented. They should be real like from appearance, behavior, mental, mind, and religious and family viewpoints.

The oddest characters can also be believable. For example; if they are immortal, this should be clarified for the addressee in order to be acceptable. Holistically, this issue has been considered in old stories.

Another significant aspect is introducing the character and his specifications to the addressee. Narration or conversation is really applicable in this regard. It is obvious that most of human personalities are implied due to his social status and mental characteristics. This is only possible through the author's thorough recognition of the character.

This technique can be directed into a consecutive character presentation and quotations are avoided. Quotations prevent innovation and attraction from the text. Moreover, the reader feels tired of just getting information. This matter is more obvious in adolescents. Whenever, his power of thinking and imaging is taken away from him. He gets bored of listening. Adolescents are not usually fond of listening to stories depriving their curiosity and recognition power.

According to Bakhtin, writer creates the character to make conversation, so human is first a speaker in story character (Okhovat, 1993, p.126-127). Robin Carr minds conversation as a perfect instrument to enrich the story he also believes that conversation feeds back personification. (Fard, 1998, p.136) Conversation increases the interactions in the story which copes with the adolescents" moods. J.N.Hooke divides character presentation into 9 categories. They can be classified into direct, indirect and mixed ones. (Hejazi, 2001,p.114).

Direct: talking about the character- it holds explaining the character and his environment

Indirect: Character speaks- it is about whatever others say about the character.

Mixed: clarifying the character's thoughts- it represents the character and doesn't judge him and defines his reactions towards others and visa-versa.

It is not recommended to use direct method a lot, while indirect method is very significant. It is hard to present character based on this method. Mixed method seems to be a good way of introduce the characters. Direct method doesn't get the power of analyzing and thinking from the addressee. It helps him recognize better. It is not limited like the indirect and conversation method.

The rewriter loans the character from the original writer. What matters is how it is nurtured according to the addressee's needs. For instance; the rewriter is better to pay more attention to characters absorbed more by the addressee and not to be a narrator in character presentation. It is better to let the characters to be introduced according to their behaviors and speech.

Due to adolescents" personalities, it is simply recognizable what types of characters please them. They are mostly interested in the characters who are superpower, hero and unbeatable and non-human with extraordinary capabilities.

\section{Conclusion}

Mansur Yarvisi considers that rewriter is the one who represents the cultural Values and human supreme thoughts and nurture the artistic competency of a nation specifically the children and adolescents (Yarvisi, 2007,p.113). The question is that can rewriting take such responsibility. The truth is that children and adults have a unique power of artistic talent; they are only attracted by new speeches. Isaac Singer thinks that adults are simply fallen asleep magnetically. University students are more simply convinced to learn something difficult. While children aren't philanthropic enough to study a book in order to help his society develop, a child is very selfish just to read an interesting story giving him the 
sense of astonishment (Hejazi, 2001,p.107). The author believes that since rewriting is very essential, a great deal of researches is required to be done in this regard and rewriting techniques should be done due to the age groups. Persian literature really needs researchers who are well - informed with the psychological issues in literature to create magnificent stories best meet the needs of their addressees.

\section{References}

Alipur, M. (2006). Ashnaee ba adabiate kudakan-an introduction to children literature. Tirgan publication.

Barythe, R. (1998). Naghad VA haghighat-criticsm and truth. Translated by Shirin dokht Daghighian. Markaz publication. Tehran.

Chambers, D. (1987). Ghesse guee VA namayeshe khalagh-Retelling story and creative presentation translated by: Soraya Ghezelayagh. Published by markaze daneshgahi.

Rampuri, G. Mohammadebene J. (1984). loghatnameye ghiasol loghat- Ghiasol loghat dictionary. Edited by: Mansur Sehat. Published by: Amir Kabir.

Colin, H. (2001). A history of childhood children and childhood in the west from medieval to modern times. Cambridge: polity Press.

Hejazi, B. (2001).Adabiate kudak Va nojavan- Children and adolescent literature aspects and specifications. Published by: Roshangaran and Motaleate zanan. Tehran.

Irani, N. (1985). Dastane taarif. abzarha VA anasor-the story of definitions. Instrument and element. Published by: Kanune paraVareshe fekrie kudakan VA nojavan. First publication.

Jafarnezhad, F. (1984). 39 essays about children literature, child book committee. Tehran.

Jalali, M. (2014). Shakheshaye eghtebas dar adabiate kudak VA nojavan (Adaptation in children's literature). Tehran: Taravat publication.

Mohammadi, M. (2000). Naghde adabiate kudak VA nojaVan-methodology of the criticism of children and adolescent literature. Published by: Sorush.

Okhovat, A. (1993). Dastur zabane dastan-story grammar. Farda Publication. Isfahan.

Plato. (2002). Jomhuriat- Republicanism. Translated by: Foad Rohani. Publisher: Elmi Farhangi.

Prop, V.Y. (1989). Rikht shenasi ghesehaye parian-Morphology of fairies tales. Translated by: Badri, Fereidun. Published by Tus.

Rahmandust, M. (1990). Adabiate kudak VA nojavan makhuse reshtehaye tarbiat moalem-adabiate Farsi, omure parvareshi VA honar-children and adolescent literature special for elementary training courses centers-Persian literature, training affairs and art. Published by: vezarate amuzesh VA parvareshi.

Rahgozar, R. (1987). VA amma baad-and hereafter. Published by: Hozeye honari. Tehran.

Shoarinezhad, J. (1995). Aliajbar, adabiate kudakan- children literature published by: Ettelaat. Tehran.

Zarrinkub, A.K. (1975). naghde adabi-Litrary criticsm. Published by: Amir Kabir. Tehran.

Yarvisi, M. (2007).Ttabassome shokufeha-the smile of the blossoms. Published by: Jahad daneshgahi. 